\title{
Enjoying Cultural Differences Assists Teachers in Learning about Diversity and Equality. An Evaluation of Antidiscrimination and Diversity Training
}

NADA TURNŠEK ${ }^{1}$

$\approx$ The present study is based on a quasi-experimental research design and presents the results of an evaluation of Antidiscrimination and Diversity Training that took place at the Faculty of Education in Ljubljana, rooted in the anti-bias approach to educating diversity and equality issues (Murray \& Urban, 2012). The experimental group included 52 in-service early childhood teachers attending the training, which consisted of a total of 120 hours. There was also a control group comprising 130 teachers. The ADT had a decisive impact on all of the measured variables: on an improvement in the participants' knowledge of discrimination, and on increased support for positive measures and for the preservation of the cultural traditions and language of immigrant children. It was found that self-assessed personality characteristics are predictors of the teachers' beliefs, especially the enjoying awareness of cultural differences variable, which correlates with all of the dependent variables.

Keywords: Early childhood; Diversity; Equality; Discrimination 


\section{Uživanje v kulturni raznolikosti je v pomoč vzgojiteljem pri izobraževanju za različnost in enakost - evalvacija izobraževanja za nediskriminacijo in raznolikost}

NADA TurnšEK

$\approx$ Študija temelji na kvazieksperimentalnem raziskovalnem načrtu; predstavlja izsledke evalvacije izobraževanja za nediskriminacijo in raznolikost, ki je potekalo na Pedagoški fakulteti v Ljubljani; utemeljeno je na antipristranskem pristopu k izobraževanju za vprašanja raznolikosti in enakosti (Murray in Urban, 2012). V eksperimentalni skupini je bilo 52 vzgojiteljev, zaposlenih v vrtcu, ki so bili deležni 120-urnega usposabljanja; v kontrolni skupini je bilo 130 vzgojiteljev. Izobraževanje je imelo odločilen vpliv na vse merjene spremenljivke: izboljšalo se je znanje udeležencev o diskriminaciji, povečala se je podpora pozitivnim ukrepom ter ukrepom ohranjanja kulturnih tradicij in jezika otrok priseljencev. Samoocene osebnostnih lastnosti so napovedovalci prepričanj vzgojiteljev, še posebej spremenljivka uživanje v zavedanju obstoja kulturnih razlik, ki je povezana $z$ vsemi odvisnimi spremenljivkami.

Ključne besede: zgodnje otroštvi, raznolikost, enakost, diskriminacija 


\section{Introduction}

Early childhood education is seen as playing a key role in combating educational disadvantages stemming from socioeconomic, cultural and/or language factors (Eurydice, 2009). Studies demonstrate the impact of quality preschools on all children's educational achievement, showing that disadvantaged children benefit the most; even long-term individual and societal benefits have been demonstrated in terms of reducing educational inequality (Heckman, 2011). However, there is growing doubt about the "formula" according to which early childhood education represents a good investment in the social state (Ruhm \& Waldfogel, 2011). Moss (2012) points out the incredulity of the 'story of high-returns', claiming that even in countries that have for decades implemented national compensatory early interventions, social inequality is still increasing. Experts problematise the implications of such an 'instrumentalisation' of preschool education - manifested in imposing the function of eliminating inequalities on preschool programmes - especially if the state does not provide effective mechanisms for reducing income inequality and social disparities in societies. As many studies show that inequality persists, Gaber and Marjanovič (2009) draw attention to the illusion that educational institutions (as well as educators) regard themselves as socially neutral and just, often combined with a belief that, solely by increasing accessibility, education institutions are doing enough to reduce inequality. It is therefore essential for those responsible for university study programmes to ask themselves what kind of conceptions, beliefs and practices they promote with regard to teachers within the existing conceptualisations of teacher education.

We argue that early childhood teacher preparation programmes need to undergo structural reforms (Florian, Young, \& Rouse, 2010) in order to adequately address issues of diversity and equality. Firstly, university programmes have to incorporate inclusive competencies as the "core competencies" of prospective early childhood teachers, representing a central role in the conceptualisation of their profession. Secondly, a significant shift away from the multicultural approach towards the anti-bias approach (Murray \& Urban, 2012) is essential, as it fosters critical reflection (Mezzirow, 1990) and an awareness of the social construction and reproduction of inequality, along with an understanding of the social and psychological mechanisms of discrimination and its prevention. The processual aspect of the reform concerns social learning occurring as a collective exercise (Ainscow \& Sandill, 2010) involving interactive methods that consider participants as dynamic actors (Boal, 20oo; Clements \& Jones, 2006; Kaikkonen, 2010). Such an approach represents a collective 
emancipatory movement that undermines the foundations of the micro-ideologies of everyday life (Ule, 2004, pp. 191-193). In this paper, we present the results of an evaluation of Antidiscrimination and Diversity Training (ADT) based on the described characteristics.

\section{Tackling inequality through early childhood education}

Transforming preschools into inclusive settings relies on a broad definition of inclusion understood in terms of responding to the diversity of all children, particularly those who are vulnerable to exclusionary pressures within society (Ainsclow et al., 2006). In Slovenia, apart from children with special educational needs due to disabilities and/or illness, children from low-income families, immigrant children (mainly from former Yugoslavia) and Roma children are also considered 'at risk' (Turnšek \& Bastič-Zorec, 2009).

Slovenian early childhood legislation and national strategic documents combine social justice policies at societal and institutional levels with recommendations on inclusive pedagogy. Priority in admission to preschools is given to children with special needs and to socially disadvantaged children. The White Paper of the Republic of Slovenia (Krek \& Metljak, 2011) envisages the increased preschool inclusion of children from socially and culturally less stimulating environments, as it promotes school readiness as well as compensating for deficiencies in learning and development (Gaber \& Marjanovič Umek, 2009). Nevertheless, as Bennett (2008) points out, family poverty and background remain significantly linked to poor educational outcomes; this is also reflected in social disparities in Slovenia's education system (Flere, 2005).

As Slovenian society shows a high level of intolerance within the European context, especially towards the Roma (Kirbiš, Flere, \& Tavčar Krajnc, 2012), Roma children are often exposed to discrimination and exclusion (Klopčič \& Polzer, 2003). They are not enrolled in preschools in adequate proportions (Strategy..., 2004), which contributes to their failure at school (Macura-Milovanović, 2006). Despite clear policy recommendations (Strategy for Roma/Gypsy Education..., 2011), national measures such as a more favourable child/adult ratio and staff reinforcement (Turnšek \& Batistič-Zorec, 2009), along with recommendations on teachers' practices (Supplement to the Curriculum..., 2002), the social inclusion of Roma children is not progressing as envisaged. Possible causes include a lack of perceived responsibility for the social inclusion of Roma children (Peček \& Macura-Milovanović, 2012; Peček Čuk, \& Lesar, 2008).

Policies fostering the inclusion of immigrant children from former Yugoslavia were introduced relatively late (National Strategy..., 2007), which, together with a high level of intolerance towards immigrants (Kirbiš, Flere, \& 
Tavčar Krajnc, 2012), contributed to the prevailing belief that immigrant status does not represent a barrier to a child's learning and development. The policies that were adopted later (Guidelines..., 2011) now provide recommendations on adapting teaching practices in line with individual learning programmes. The White Paper obliges preschools to organise lessons for learning Slovenian, as well as support in the child's mother tongue. Still, immigrant children often achieve worse learning results than other children due to linguistic and cultural differences combined with their low socioeconomic status (Dekleva \& Razpotnik, 2002; Macura-Milovanović, 2006; Peček \& Lesar, 2006).

\section{From multiculturalism to an anti-bias approach}

Until recently, two approaches to educating diversity and equality prevailed in the conceptualisation of teacher education: the multicultural approach and the intercultural approach. The multicultural approach acknowledges the need for the recognition and celebration of different cultures in early childhood settings. However, its sole focus on cultural diversity, particularly on those aspects of culture that appear interesting, exotic and different, poses the risk of confirming or strengthening stereotypes, and thus perpetuating the perception of minority cultures being different to what is normal. Even though the intercultural approach goes one step further by fostering understanding and respect between majority and minority cultures, both fail to address the broader societal context in which diversity and inequality exists, including prejudice, discrimination, racism and power (Murray \& Urban, 2012, pp. 116-117).

The fundamental characteristics of the anti-bias approach to educating diversity and equality issues described by Murray \& Urban (2012, pp. 118-127) can be summarised as its proactive, value-based and activist orientation that recognises the influence of the societal context on generating equality or inequalities along with power issues in societies and preschools. It supports teachers in the process of becoming critically reflective practitioners who are able to reflect on belief systems as a significant element of the institutional 'hidden curricula' (see Jackson, 1968; Apple, 1982), and who are "conscious of the influence of their assumptions and belief systems on behaviour" towards others (Mezzirow, 1990, as cited in Murray \& Urban, 2012, pp. 92-98). As Mac Naughton (2003, p. 3) points out, early childhood professionals also need to examine "the social and political factors that produce knowledge and practices, together with the use of this knowledge to strategically transform education in socially progressive directions". By providing a transformative teacher education experience, the anti-bias approach therefore promotes a consciousness of teaching as a political act (Kozleski \& Waitoller, 2010). 


\section{Antidiscrimination and Diversity Training: Goals and content}

The first stage of the ADT focuses on participants' self-perception and identity, followed by an exploration of the influences that affect our perceptions of others. Participants explore the images and stories concerning other groups that we create on the basis of our own societal or cultural background; the aim is to foster an understanding that a perception of one's identity can only be constructed through its opposition, through the ultimately different Other (Hall, 2007).

The next stage involves identifying dominant negative stereotypes and prejudices (including those relevant to preschools) in order to recognise their evaluative, affective and conative components (Augoustinos \& Walker, 1995, p. 230). The training supports the recognition of stereotypes and prejudices as those attitudes that foster maximisation of the perceived differences between groups (Tajfel, 1978).

Further activities promote an understanding that the emergence and reinforcement of stereotypes and prejudices is not an individual or cognitive process, but rather a collective and ideological one. Participants are made aware of the written and spoken messages that surround us in everyday life, such as fairy tales, songs and sayings, which influence our thinking about minority groups. Exploring the so-called "common knowledge" of the society can lead to the realisation of the limiting and stereotyping effects of such messages. Here, the focus is also on the role of the political sphere, the media and education in maintaining inequality. Participants become aware that stereotypes function as a motivation and legitimisation of discriminatory practices (Van Dijk, 2005), e.g., through exclusion from, or the unequal distribution of, social resources or human rights, which in turn produce, determine and objectify cognitive and affective structures concerning minority groups (Augoustinos \& Walker, 1995, p. 222).

Further steps involve the promotion of tolerance and empathy; participants are encouraged to identify with various marginalised positions. Activities lead to the acknowledgement that our own cultural background also equips us with distinctive 'cultural glasses' that influence our perceptions of others. Analysis of discriminatory situations represents the basis for embracing the advocacy aspects of the professional role. By addressing the concept of equal opportunities, participants are made aware that children start their lives from different positions; at this stage, the key goal is to raise awareness of the importance of positive measures as a key means of achieving equality. 


\section{The problem}

Although undergraduate early childhood study prior to the Bologna reform did contribute to Slovene teachers' pro-democratic orientations and to respecting diversity on the whole, it did not challenge deeply rooted ethnocentric positions (Turnšek, 2006; Turnšek \& Pekkarinen, 2009). Teachers' attitudes concerning immigrant families and children represented significant exceptions in the general democratic orientation (Turnšek \& Pekkarinen, 2009), as (only) about half of teachers advocated the preservation of immigrants' customs, traditions and languages; among the rest, a tendency towards the denial of cultural rights or assimilation was identified. Since the data for teachers did not deviate from general Slovenian public opinion, it was concluded the prevailing cultural values had been accepted.

In teachers' interpretations, equality of opportunities was often confined to the notion of preschools' (social) accessibility; the strong presence of a common-sense conception has also been identified, characterised by the "demand" to treat all children in the same way. Less than one third of teachers supported the interpretation requiring individualisation and differentiation.

At the time, the research results indicated that early childhood teachers mainly associate justice with formal equality, but not with differential treatment. In response to the research findings, the Counter-Discriminatory Practice course was introduced within the framework of Bologna-reformed postgraduate early childhood study, within which the Antidiscrimination and Diversity Training was implemented. This course focused special attention on the teachers' understanding of the differential treatment - in terms of pedagogical practices and policies - with which teachers and preschools can promote justice. This is also in line with the White Paper (Krek \& Metljak, 2011, pp. 14-15), which defines equity in education as a "key element of social justice", obliging the state to "adopt various measures and policies including positive discrimination for children from socially and culturally disadvantaged backgrounds", stressing the demand for non-biased or non-discriminatory treatment.

The study presented here answers the following research questions: Does ADT have a significant impact on the participants' knowledge of discrimination, on their attitudes towards the differential treatment of at-risk children and towards maintaining the cultural identity of immigrant children? To which factors are these positions related?

\section{Method}

The experimental group consisted of 52 early childhood student teachers (participants) who had completed the three-year undergraduate Early 
Childhood Education Study Programme ${ }^{2}$ and had continued studying at the two-year postgraduate level; within this programme, they attended the ADT, consisting of 60 hours of workshops and 60 hours of independent study (e.g., writing reflections, etc.). The control group included 130 teachers with the same level and type of education extracted from a random sample of Slovenian teachers (non-participants). ${ }^{3}$ A comparison of the characteristics of both groups shows no significant differences, apart from the average older age of the participants due to the fact that the postgraduate study programme is also attended by teachers and headmasters with many years of work experience.

In order to assess the participants' initial knowledge and beliefs, they were asked to complete an evaluation pre-questionnaire prior to the ADT in September 2010. The questionnaire was designed to evaluate the achievement of the following key ADT objectives: improving knowledge of discrimination, understanding the importance of differential treatment in achieving equal opportunities, and changing the participants' attitudes in favour of preserving immigrant children's mother tongue and their culture, customs and habits in preschool.

Shortly thereafter, the questionnaire was sent to the non-participants by post; $98 \%$ of the completed questionnaires were returned in the following three weeks. At the end of the last ADT workshop in December 2010, the participants completed a post-questionnaire containing the same set of questions. The daily ADT schedule consisted of three to four workshops, lasting about five hours in total.

An analysis of variance was used to determine the significance of the differences in the participants' knowledge and beliefs between the pre-testing and post-testing compared to those of the control group. Using Tukey's HSD posthoc test, we established which group means differ significantly from each other. A multiple regression analysis was performed to establish which independent variables are predictors of the respondents' knowledge and beliefs (Table 1). These predictors were assumed to be: personal (age), professional (length of service in preschools), family-related (parents' education), personality characteristics (preferences indicating "openness/closeness" towards people of a different ethnicity and/or cultural background, preference to live in a diverse environment), environmental (population diversity in the place of residence), and lifestyle factors (having immigrant friends, travelling abroad) (Table 2).

2 At any of the universities in Slovenia: in Ljubljana, Koper or Maribor.

3 First, the teachers working in the same preschool institutions as the participants were included in the whole Slovenian sample. In the second phase, we randomly selected preschools in the remaining 12 statistical regions in Slovenia and added these teachers to the sample. In the third phase, we formed the control group by selecting only those teachers who had completed the same formal education: the 3-year undergraduate Early Childhood Education Study Programme. 
Table 1. The dependent variables.

\begin{tabular}{llc}
\hline Variable name & Variable description & Range \\
\hline DISCRIMINATION & $\begin{array}{l}\text { The total number of correctly identified situations of dis- } \\
\text { crimination or non-discrimination. Correct answer = value 1; } \\
\text { Incorrect answer = value 0. }\end{array}$ & $0-8$ \\
\hline POSITIVE & $\begin{array}{l}\text { Assessment of positive measures (a list of 12 statements) as } \\
\text { being just (value = 10) or unjust (value = 0) on a semantic } \\
\text { differential scale. }\end{array}$ & $0-120$ \\
\hline MEASURES & $\begin{array}{l}\text { Agreement with attitudes to immigrants (a list of 12 attitudes) } \\
\text { on a Likert attitude scale from strongly disagree = value 1 to } \\
\text { fully agree = value 5. }\end{array}$ & $12-60$ \\
\hline IMMIGRANTS &
\end{tabular}

Table 2. The independent variables.

\begin{tabular}{|c|c|}
\hline group & Experiment - T (pre-testing), Experiment - T2 (post-testing), Control \\
\hline cautious & $\begin{array}{l}\text { I am usually cautious during contact with people from another culture } \\
\text { (from Not at all true }=1 \text { to Very true }=5 \text { ). }\end{array}$ \\
\hline enjoy & $\begin{array}{l}\text { I enjoy my awareness that there are cultural differences between myself } \\
\text { and other people (from Not at all true }=1 \text { to Very true }=5 \text { ). }\end{array}$ \\
\hline try to learn & $\begin{array}{l}\text { When I make contact with people from different cultures, I try to learn as } \\
\text { much as possible about their life (from Not at all true }=1 \text { to Very true }=5 \text { ). }\end{array}$ \\
\hline avoid & $\begin{array}{l}\text { If possible, I prefer to avoid situations that involve contacting people from } \\
\text { a different cultural environment (from Not at all true }=1 \text { to Very true }=5 \text { ). }\end{array}$ \\
\hline age & Number of years. \\
\hline neighbourhood & $\begin{array}{l}\text { How would you describe the neighbourhood in which you live? As an area } \\
\text { where almost nobody (some people, many people) has a different ethni- } \\
\text { cal origin than the majority of residents of Slovenia. }\end{array}$ \\
\hline education: mother & $\begin{array}{l}\text { Please indicate the last level of education your mother completed (incom- } \\
\text { plete primary school, primary school, 2- or 3-year vocational school, 4- or } \\
5 \text {-year secondary school, 2-year post-secondary school, 3-year higher } \\
\text { vocational programme, university education (faculty, academy, specialisa- } \\
\text { tion, master's degree, doctorate)). }\end{array}$ \\
\hline education: father & $\begin{array}{l}\text { Please indicate the last level of education your father completed (same } \\
\text { modalities as for the education: mother variable). }\end{array}$ \\
\hline work experience & Number of years. \\
\hline travel & $\begin{array}{l}\text { How often do you travel abroad? (A few times a year, } 2-3 \text { times a year, } \\
\text { once a year, every few years, never). }\end{array}$ \\
\hline friends & $\begin{array}{l}\text { Do you have any friends who have moved to Slovenia from another coun- } \\
\text { try? (No, I have none; yes; I have some; yes, I have many). }\end{array}$ \\
\hline like to live & $\begin{array}{l}\text { Suppose you could choose where you would like to live. In which of the } \\
\text { three areas listed below would you like to live if you had the choice? (In } \\
\text { an area where almost nobody (some people, many people) has a different } \\
\text { ethnic origin than the majority of residents of Slovenia). }\end{array}$ \\
\hline
\end{tabular}

\section{Results}

\section{Understanding discrimination}

The ADT aimed at improving the participants' ability to recognise various manifestations of direct and indirect discrimination, as well as to distinguish 
them from cases of positive discrimination (or positive measures). They were asked to read descriptions of various situations and decide whether the acts mentioned constitute discrimination or not.

Table 3. The cases of discrimination - the shares of correct answers.

\begin{tabular}{lccc}
\hline & $\begin{array}{c}\text { Group } \\
\text { Experiment-T1 } \\
\mathbf{N}=\mathbf{5 2}\end{array}$ & $\begin{array}{c}\text { Group } \\
\text { Experiment-T2 } \\
\mathbf{N = 5 2}\end{array}$ & $\begin{array}{c}\text { Group } \\
\text { Control } \\
\mathbf{N}=\mathbf{1 3 0}\end{array}$ \\
\hline Musical ear & $29.4 \%$ & $55.8 \%$ & $19.4 \%$ \\
Roma/employment & $73.1 \%$ & $76.9 \%$ & $67.7 \%$ \\
Age/marital status & $55.8 \%$ & $76.9 \%$ & $53.5 \%$ \\
Women/quota & $55.8 \%$ & $80.8 \%$ & $27.7 \%$ \\
Gay & $96.2 \%$ & $98.1 \%$ & $88.5 \%$ \\
Asthma & $80.8 \%$ & $98.1 \%$ & $80.8 \%$ \\
Roma/restaurant & $88.5 \%$ & $100.0 \%$ & $75.0 \%$ \\
Enrolment criteria & $40.4 \%$ & $76.9 \%$ & $20.5 \%$ \\
\hline
\end{tabular}

After completing the training, the participants' ability to identify direct discrimination (see Appendix, statements No. 1, No. 2 and No. 3) improved. There was an increase in the share of participants who understood that a Roma person is discriminated against if they are forbidden to enter a restaurant, that a child is discriminated against if they are not allowed to attend preschool because of asthma, and that a gay teacher is discriminated against if they lose their job because of their sexual orientation (Table 3 ). In the process of learning through group experiences and discussions, the participants increased their ability to use the comparable situations concept (Manual for Trainers, 2006): they learned that discrimination occurs if one person is treated less favourably than another in a similar situation on any grounds, including racial or ethnic origin as well as other characteristics defined by law.

The share of participants identifying indirect discrimination (see Appendix, statements No. 4, No. 5 and No. 6) increased in all cases (Table 3). The participants learned that enrolment criteria that give priority to children whose parents are employed and have a permanent residence are only seemingly justified. Although the argument that these children are most "in need" of full-day care is plausible, the teachers learned that such criteria also place the children of unemployed parents, who often have a low income, at a disadvantage, as well as those with a temporary residence or without citizenship (potentially immigrants, foreigners and Roma children). Furthermore, an improvement was shown in the participants' understanding that the restriction on enrolment in an early childhood study programme based on the candidates' musical ear is 
only apparently neutral, and is therefore discriminatory for two reasons: firstly, because a musical ear is not an essential competence for the early childhood profession and, secondly, because access to the study programme is limited on the basis of a person's inborn characteristic. A similar substantive analysis was required in the case of job reductions; after completing the training, more participants recognised discrimination in criteria whereby a teacher loses their job on the grounds of their personal attributes, such as age and marital status, rather than on those related to their job description.

There was also an increase in the share of participants who fully understood positive measures, such as a quota for women in political parties or a job quota (see Appendix, statements No. 7 and No. 8), as a means of ensuring equal opportunities (Table 3 ).

Table 4. Tukey HSD test - variable DISCRIMINATION.

\begin{tabular}{lccc}
\hline & $\{1\}$ & $\{2\}$ & $\{3\}$ \\
\hline Control $\{1\}$ & & 0.2237 & 0.0000 \\
Experiment - T1 $\{2\}$ & 0.2237 & & 0.0000 \\
Experiment - T2 $\{3\}$ & 0.0000 & 0.0000 \\
\hline \multicolumn{4}{l}{ Marked differences are significant at $\mathrm{p}<.05000$}
\end{tabular}

Initially, there were no significant differences between the participants and the control group, while the differences between the participants' positions prior to and after the ADT were clearly significant (Table 4).

\section{Supporting positive measures}

The ADT aimed at raising awareness of the role of positive measures in ensuring equal opportunities of the following "at-risk" groups: children with special needs, immigrant children, Roma, and socially disadvantaged children. The participants assessed the measures listed on a ten-point scale ranging from unjust to just. 
Table 5. Positive measures - Means, Std. Dev.

\begin{tabular}{|c|c|c|c|c|c|c|}
\hline \multirow{2}{*}{ The preschool provides and finances ... } & \multicolumn{2}{|c|}{$\begin{array}{l}\text { Experim-T1 } \\
\mathrm{N}=52\end{array}$} & \multicolumn{2}{|c|}{$\begin{array}{l}\text { Experim-T2 } \\
\qquad \mathrm{N}=52\end{array}$} & \multicolumn{2}{|c|}{$\begin{array}{l}\text { Control } \\
\mathrm{N}=130\end{array}$} \\
\hline & Mean & Std. Dev. & Mean & Std. Dev. & Mean & Std. Dev. \\
\hline $\begin{array}{l}\text {... lessons in learning the Slovenian } \\
\text { language for immigrant children. }\end{array}$ & 7.2 & 1.4 & 9.4 & 2.1 & 6.1 & 2.7 \\
\hline $\begin{array}{l}\text {... children's picture books in Braille and } \\
\text { stories on CDs for blind children. }\end{array}$ & 7.5 & 0.9 & 9.6 & 1.2 & 7.2 & 1.9 \\
\hline $\begin{array}{l}\text {... the admission of Roma children to } \\
\text { preschools free of charge. }\end{array}$ & 4.8 & 2.7 & 7.4 & 2.8 & 3.5 & 3.6 \\
\hline $\begin{array}{l}\text {... an afternoon programme providing } \\
\text { reading and socialising for immigrant } \\
\text { children and parents in their mother } \\
\text { tongue. }\end{array}$ & 6.9 & 1.6 & 9.2 & 1.6 & 5.4 & 3.1 \\
\hline $\begin{array}{l}\text {... an additional expert worker offering } \\
\text { support to autistic children. }\end{array}$ & 7.6 & 0.8 & 9.9 & 1.1 & 7.4 & 1.6 \\
\hline $\begin{array}{l}\text {... counselling support for Roma families } \\
\text { in their homes. }\end{array}$ & 6.5 & 1.8 & 8.7 & 1.9 & 4.6 & 3.3 \\
\hline $\begin{array}{l}\text {... the admission of chronically ill chil- } \\
\text { dren to preschools free of charge. }\end{array}$ & 6.5 & 2.2 & 8.8 & 2.7 & 5.7 & 2.8 \\
\hline $\begin{array}{l}\text {... playtime hours carried out by teach- } \\
\text { ers inside a Roma neighbourhood for } \\
\text { the purpose of gaining the greater trust } \\
\text { of Roma families in the preschool. }\end{array}$ & 6.6 & 2.0 & 8.7 & 2.1 & 5.4 & 2.9 \\
\hline $\begin{array}{l}\text {... holidays for socially disadvantaged } \\
\text { children free of charge. }\end{array}$ & 7.4 & 1.2 & 9.5 & 1.6 & 6.8 & 2.3 \\
\hline $\begin{array}{l}\text {... an afternoon preschool programme } \\
\text { for children of families where both } \\
\text { parents are unemployed. }\end{array}$ & 5.5 & 3.0 & 7.7 & 2.7 & 4.1 & 3.8 \\
\hline $\begin{array}{l}\text {... the admission of children from } \\
\text { families that receive social assistance } \\
\text { benefits to preschools free of charge. }\end{array}$ & 6.5 & 2.0 & 8.8 & 2.0 & 5.6 & 3.0 \\
\hline $\begin{array}{l}\text {... a temporary translator for the } \\
\text { adjustment period of a child who has } \\
\text { immigrated to Slovenia. }\end{array}$ & 6.5 & 1.9 & 8.5 & 2.2 & 5.4 & 3.0 \\
\hline
\end{tabular}

Prior to the ADT, the participants' scores ranged from 6.5 to 7.6 , revealing a slight tendency towards assessing the measures as just (with the exception of a lower score for admission for Roma children to preschools free of payment); on completing the ADT, all of the scores increased. In all cases, the scores of the non-participants were lower (Table 5). A similar pattern emerged when observing the scores of all respondent groups: the set of measures aimed at children with special needs on average gained the highest scores, followed by those aimed at immigrants and socially disadvantaged children, with the lowest scores concerning Roma children. The lowest overall support for measures targeting Roma children is particularly apparent when comparing the same measure for the different at-risk children, i.e., admission 
to preschool free of payment; again there was greater support for poor and chronically ill children.

Table 6. Tukey HSD test - variable POSITIVE MEASURES.

\begin{tabular}{lccc}
\hline & $\{1\}$ & $\{2\}$ & $\{3\}$ \\
\hline Control $\{1\}$ & & 0.0035 & 0.0000 \\
Experiment - T1 $\{2\}$ & 0.0035 & & 0.0451 \\
Experiment - T2 \{3\} & 0.0000 & 0.0451 & \\
\hline
\end{tabular}

Marked differences are significant at $\mathrm{p}<.05000$

The Tukey's HSD shows that the participants' overall agreement with the measures was significantly higher than that of the non-participants; however, the ADT still significantly increased the participants' assessment of the measures as being closer to just (Table 6).

\section{Preserving immigrant children's cultural traditions and language}

Previous research showed that nearly half of teachers were not in favour of preserving immigrant children's mother tongue and their culture, customs and habits in preschool (Turnšek \& Pekkarinen, 2009). Even those whose rhetoric strongly advocated equality often expressed "reservations". The counterarguments were based on the belief that using the mother tongue and exposing cultural habits does not benefit immigrant children's socialisation and their subsequent school performance; we label these arguments as pragmatic, as they express "what is best for children". The second type of argumentation is grounded on an ethnocentric position claiming that immigrant children should adjust to Slovenian culture. We label these beliefs as ideological, because they reflect "what is right or wrong in principle". The respondents in our research indicated their agreement with the statements on a Likert scale. 
Table 7. Attitudes to immigrants - Mean, Std. Dev.

\begin{tabular}{|c|c|c|c|c|c|c|}
\hline & \multicolumn{2}{|c|}{$\begin{array}{c}\text { Experim-T1 } \\
\mathrm{N}=52\end{array}$} & \multicolumn{2}{|c|}{$\begin{array}{c}\text { Experim-T2 } \\
\mathrm{N}=52\end{array}$} & \multicolumn{2}{|c|}{$\begin{array}{l}\text { Control } \\
\mathrm{N}=130\end{array}$} \\
\hline & Mean & Std. Dev. & Mean & Std. Dev. & Mean & Std. Dev. \\
\hline $\begin{array}{l}\text { Immigrant parents should speak Slove- } \\
\text { nian with their children since in this way } \\
\text { they show their respect for the country } \\
\text { to which they have moved. }\end{array}$ & 1.83 & 0.90 & 1.40 & 0.53 & 2.45 & 1.16 \\
\hline $\begin{array}{l}\text { Immigrant parents provide the best } \\
\text { assistance for their children's social } \\
\text { integration if they also speak Slovenian } \\
\text { with them in their home environment. }\end{array}$ & 2.62 & 1.21 & 1.92 & 1.01 & 3.00 & 1.21 \\
\hline $\begin{array}{l}\text { Children's perception of the Slovenian } \\
\text { language as the national language is } \\
\text { one of the most important objectives of } \\
\text { the early childhood curriculum. }\end{array}$ & 3.50 & 0.94 & 3.25 & 1.15 & 3.73 & 1.08 \\
\hline $\begin{array}{l}\text { It is most beneficial for immigrant } \\
\text { children to only speak the Slovenian } \\
\text { language because this ensures they will } \\
\text { have good academic performance later } \\
\text { in school. }\end{array}$ & 1.87 & 0.82 & 1.71 & 0.78 & 2.13 & 0.91 \\
\hline $\begin{array}{l}\text { It would set a bad example for others } \\
\text { if a preschool teacher were to speak } \\
\text { with immigrant children in their own } \\
\text { language. }\end{array}$ & 1.60 & 0.66 & 1.60 & 0.80 & 2.12 & 0.86 \\
\hline $\begin{array}{l}\text { At preschool, it is best for immigrant } \\
\text { children to only speak Slovenian, as this } \\
\text { ensures that they will be accepted by } \\
\text { their peers when playing together. }\end{array}$ & 2.37 & 1.01 & 2.02 & 1.06 & 2.58 & 1.10 \\
\hline $\begin{array}{l}\text { The teacher would act unprofessionally } \\
\text { if she/he were to allow Serbian parents } \\
\text { to present their Orthodox holiday } \\
\text { to children in a Slovenian preschool } \\
\text { institution. }\end{array}$ & 1.46 & 0.85 & 1.21 & 0.46 & 1.68 & 0.77 \\
\hline $\begin{array}{l}\text { It is best for immigrant children to not } \\
\text { visit their native country often to avoid } \\
\text { experiencing distress. }\end{array}$ & 1.19 & 0.44 & 1.17 & 0.38 & 1.47 & 0.61 \\
\hline $\begin{array}{l}\text { I find it disrespectful of immigrant } \\
\text { parents if they talk with their children in } \\
\text { their language in the preschool centre's } \\
\text { cloakroom. }\end{array}$ & 1.33 & 0.51 & 1.19 & 0.40 & 1.65 & 0.75 \\
\hline $\begin{array}{l}\text { In order to avoid circumstances in } \\
\text { which immigrant children would feel } \\
\text { vulnerable, it is better that at preschool } \\
\text { the teacher does not carry out any } \\
\text { activities related to their culture. }\end{array}$ & 1.44 & 0.57 & 1.23 & 0.47 & 1.62 & 0.74 \\
\hline
\end{tabular}

The participants' agreement with the statements, indicated at a level between 1 and 2, demonstrate their (strong) disagreement with most statements even prior to the ADT, except for two statements concerning immigrant children learning the Slovenian language (Table 7). 
Table 8. Tukey HSD test - variable ATTITUDES-IMMIGRANTS.

\begin{tabular}{lccc}
\hline & $\{1\}$ & $\{2\}$ & $\{3\}$ \\
\hline Control $\{1\}$ & & 0.0033 & 0.0000 \\
Experiment - T1 $\{2\}$ & 0.0033 & & 0.0334 \\
Experiment - T2 $\{3\}$ & 0.0000 & 0.0334 & \\
\hline
\end{tabular}

Marked differences are significant at $p<.05000$

The participants' overall agreement with the statements relating to immigrant children/parents was significantly lower than that of the non-participants; on completion of the ADT, the participants' agreement decreased significantly (Table 8).

\section{Factors related to the teachers' positions}

Multiple regression analysis shows that among all of the independent variables only the variable ENJOY is a significant predictor of (all of) the respondents' knowledge of discrimination (DISCRIMINATION); $\mathrm{R}^{2}$ explains $18 \%$ of the variance. The positive relationship indicates that those respondents who described themselves as people who enjoy their awareness that there are cultural differences between themselves and other people performed better in identifying the discriminatory situations (Beta $=0.16 ; \mathrm{B}=0.282 ; \mathrm{p}=0.044$ ). The variables ENJOY and TRY TO LEARN are predictors of the respondents' assessments of the positive measures; $\mathrm{R}^{2}$ explains a total of $17 \%$ of the variance. Those respondents who described themselves as people who enjoy cultural differences ... and/or try to learn as much as possible about the life of people from different cultures consider the positive measures to be just to a greater extent (ENJOY, Beta $=0.19 ; \mathrm{p}=0.014 ;$ TRY TO LEARN, Beta $=0.18 ; \mathrm{p}=0.032)$. The variables ENJOY, TRY TO LEARN, FRIENDS, CAUTIOUS and AVOID are predictors of the respondents' attitudes towards immigrant children; $\mathrm{R}^{2}$ explains a total of $33 \%$ of the variance. Respondents who enjoy cultural differences; try to learn more about other people's lives; are not cautious during contact with people from another culture; and do not avoid them, as well as those who have many friends with an immigrant background express significantly less agreement with the arguments opposing the preservation of immigrant children's culture and language (ENJOY, Beta $=0.24 ; \mathrm{p}=0.001 ;$ TRY TO LEARN, Beta $=0.23 ; \mathrm{p}=0.001$; FRIENDS, Beta $=0.16 ; \mathrm{p}=0.021 ;$ CAUTIOUS, Beta $=-0.16 ; \mathrm{p}=0.028 ; A V O I D$, Beta $=-0.15 ; \mathrm{p}=0.041)$. 


\section{Conclusions and discussion}

The Antidiscrimination and Diversity Training clearly helped reshape the student teachers' orientations regarding diversity and equality issues, as after the training significant differences were found in their beliefs and knowledge, or the initial differences between those not involved in the ADT and the participants increased "in favour" of the latter. The overall positive impact might also be attributed to the participants' high satisfaction with the ADT, especially with the methods of learning; according to the participants, sharing and exchanging their experiences and views within the group helped to raise their awareness of the key concepts related to diversity and equality.

The ADT had a decisive impact on the participants' ability to identify those key circumstances that define discrimination through the use of the comparable situations concept, as well as the apparently neutral concept, which is crucial for defining hidden discrimination. Equipping teachers with knowledge of discrimination represents a good starting point for asserting the advocacy aspects of their professional role. Moreover, differential and/or preferential treatment became strongly incorporated into the teachers' conceptualisation of equality, partly due to the ADT, which strengthened their perception of positive measures as important instruments in reaching the political aim of equal opportunities. The ADT thus contributed to eliminating the main barrier to the implementation of inclusion, i.e., the prevailing belief that any kind of special treatment represents injustice, as was recognised in earlier studies.

However, the teachers do not perceive all vulnerable life circumstances as involving the same level of risk: not surprisingly, children with special needs are seen as those who are the most "entitled to" additional support. We assume that the attribution of helplessness and responsibility plays an important role in determining who is entitled to special treatment. In other words, teachers tend not to doubt that children with physical impairments are indeed in the most disadvantaged position, as they cannot adequately help themselves without the support of others, and cannot assume responsibility for improving their own situation. On the other hand, it does not seem equally self-evident that a child who does not speak the Slovenian language, or who comes from another cultural background, also needs support in order to learn and socialise. Recognition of the need for additional support is the weakest in the case of Roma children, which is surprising given the fact that the accumulation of risk factors is particularly associated with a Romany background. In this respect, the study indicates the teachers' "differentiated approach to differential treatment". 
The present study suggests that teachers' intrinsic motivation for improving their knowledge and professional growth might be a more reliable predictor of their positions than the education they have acquired; even though the teachers from the representative Slovenian sample had the same level and type of education as the teachers involved in the ADT, they initially demonstrated less support for positive measures and agreed more with attitudes opposing immigrants' right to preserve their own culture. We argue that the determining feature of the participants was that they have continued their education at postgraduate level. In this regard, the results correspond to previous research results (Turnšek \& Pekkarinen, 2009).

Finally, the study draws attention to teachers' self-perception as an important factor related to their orientation towards diversity and equality (whereas personal and professional circumstances, such as work experience, living in a culturally diverse environment, parental education, etc., show no such relation). Enjoying (not simply accepting) cultural differences between people is the key determining factor, especially when combined with a genuine interest in understanding others or their way of life, and having others within one's friendship network. This set of interrelated self-assessed personality characteristics reflecting an "openness towards otherness" is unambiguously related to greater support for immigrants' cultural rights, as well as for positive measures supporting at-risk children, even with a better knowledge of discrimination. Further research is needed in order to explore the role of other potential (subjective) factors in the professional development of teachers.

\section{References}

Ainscow, M., Booth, T., Dyson, A., Farrell, P., Frankham, J., Gallannaugh, F., Howes, A., \& Smith, R. (2006). Improving schools, developing inclusion. London: Routledge. Retrieved July 32013 from http:// www.oecd.org/development/anewparadigmfordevelopment.htm Ainscow, M., \& Sandill, A. (2010). Developing inclusive education systems: The role of organisational cultures and leadership. International Journal of Inclusive Education, 14(4), 401-416.

Apple, M. W. (1982). Education and power. Boston: Routledge and Kegan Paul.

Augoustinos, M., \& Walker, I. (1995). Social cognition. London: Sage.

Bennett, J. (2008). Early childhood services in the OECD countries: A review of the literature and of current policy in the early childhood field, Innocenti Working Paper No. 2008-01. Florence: UNICEF, Innocenti Research Centre.

Berger, L. M., Paxson, C., \& Waldfogel, J. (2009). Income and child development. Children and Youth Services Review, 31(9), 978-989.

Boal, A. (2000). Theater of the oppressed. London: Pluto Press. 
Clements, P., \& Jones, J. (2006). The diversity training handbook. London: Kogan Page.

Dekleva, B., \& Razpotnik, Š. (2002). Čefurji so bili rojeni tu: življenje mladih priseljencev druge generacije v Ljubljani. [Chefurs were Born Here: The Life of Second-Generation Young Migrants in Ljubljana]. Ljubljana: Faculty of Education, Institute for Criminology at the Faculty of Law.

Dodatek h Kurikulu za vrtce za otroke Romov. [Supplement to the curriculum for educational work with Roma children]. (2002). Ljubljana: Ministry of Education and Sport. Retrieved July 32013 from http://www.mss.gov.si/ fileadmin/mss.gov.si/pageuploads/podrocje/vrtci/pdf/vrtci_Dodatek_-_

ROMI.pdf

Eurydice 2009. Tackling social and cultural inequalities through early childhood education and care in Europe. Brussels: EACEA

Flere, S. (2005). Social inequity and educational expansion in Slovenia. Educational Studies, 31(4), $449-464$.

Florian, L., \& Kershner, R. (2009). Inclusive pedagogy. In H. Daniels, J. Porter, \& H. Lauder, (Eds.), Knowledge, values and educational policy: A critical perspective (pp. 173-183). London: Routledge. Gaber, S., \& Marjanovic Umek, L. (2009). Študije (primerjalne) neenakosti. Znanstvena poročila Pedagoškega inštituta 21/o9. [Studies of (comparative) inequality. Scientific reports of the Educational Research Institute of 21/o9]. Ljubljana: Educational Research Institute.

Hall, S. (2007). Who needs “identity”? In P. Du Gay, J. Evans, \& P. Redman (Eds.), Identity: A reader (pp. 15-30). London: SAGE.

Heckman, J. J. (2011). The economics of inequality: The value of early childhood education. American Educator, 35(1) 31-35.

Kaikkonen, L. (2010). Promoting teacher development for diversity. In R. Rose (Ed.), Confronting obstacles to inclusion: International responses to developing inclusive education (pp. 1-6). Abingdon: Routledge.

Kirbiš, A., Flere, S., \& Tavčar Krajnc, M. (2012). Netolerantnost v Sloveniji in Evropi: primerjalna longitudinalna analiza. [Intolerance in Slovenia and Europe: A comparative longitudinal analysis]. Družboslovne razprave, XXVIII(70), 27-50.

Klopčič, V., \& Polzer, M. (2003). Evropa, Slovenija in Romi. [Europe, Slovenia and Roma]. Retrieved July 32013 from http://www.inv.si/DocDir/PublikacijePDF/2003/evropa,\%2oslovenija\%2oin\%2o romi_optimized.pdf

Kozleski, E. B., \& Waitoller, F. (2010). Teacher learning for inclusive education: Understanding teaching as a cultural and political practice. International Journal of Inclusive Education, 14(7), $655-666$.

Krek, J., \& Metljak, M. (Eds.) (2011). Bela knjiga o vzgoji in izobraževanju v Republiki Sloveniji 2011. [White Paper on Education in the Republic of Slovenia 2011]. Ljubljana: Educational Research Institute.

Mac Naughton, G. (2003). Shaping early childhood: Learners, curriculum and contexts. Berkshire:

Open University Press.

Macura-Milovanović, S. (2006). Socijalni aspekt inkluzije romske dece iz naselja Deponija u 
obrazovni sistem. [Social aspect of the inclusion of Roma children from the Deponija settlement into the education system]. Pedagogija, LXI(3), 304-320.

Manual for Trainers - Workshops to Counteract Discrimination. (2006). Ljubljana: ZARA.

Mezzirow, J. (1990). Fostering critical reflection in adulthood: A guide to transformative and emancipator learning. San Francisco: Jossey-Bass Publishers.

Murray, C., \& Urban, M. (2012). Diversity and equality in early childhood: An Irish perspective.

Dublin: Gill \& Macmillan.

Peček, M., \& Lesar, I. (2006). Pravičnost slovenske šole: Mit ali realnost [Justice of the Slovenian school: Myth or reality?]. Ljubljana: Sophia.

Peček Čuk, M., \& Lesar, I. (2008). Teachers' perceptions of the inclusion of marginalised groups.

Educational Studies, 34(3), 225-239.

Peček, M., \& Macura-Milovanović, S. (2012). Who is responsible for vulnerable pupils? The attitudes of teacher candidates in Serbia and Slovenia. European Journal of Teacher Education, 35(3), 327-346. Ruhm, C. J., \& Waldfogel, J. (2011). Long-term effects of early childhood care and education. Institute for the Study of Labor. IZA Discussion Paper No. 6149. Retrieved July 32013 from http://ssrn.com/ abstract $=1968100$

Smernice za vključevanje otrok priseljencev v vrtce in šole. [Guidelines for the integration of immigrant children in preschools and schools]. (2011). Ljubljana: Institute of RS for Education and Sport. Retrieved July 32013 from http:// www.zrss.si/pdf/250811092039_smernice_-dopolnitev.pdf Strategija vzgoje in izobraževanja Romov v Republiki Sloveniji. [Strategy of Education and Training of Roma Children in the Republic of Slovenia]. (2004). Retrieved July 32013 from www.mizks.gov.s/ fileadmin/mizks.../o721_- strategija Romi.doc

Strategija vzgoje in izobraževanja Romov v Republiki Sloveniji. [Strategy of Education and Training of Roma Children in the Republic of Slovenia]. (2011). Retrieved July 32013 from http:// www. mss.gov.si/fileadmin/mss.gov.si/pageuploads/podrocje/razvoj_solstva/projekti/Strategija_Romi_ dopolnitev_2011.pdf

Strategija vključevanja otrok, učencev in dijakov migrantov v sistem vzgoje in izobraževanja v Republiki Sloveniji. [National strategy for the social inclusion of migrant children and youth into the education system in the Republic of Slovenia]. (2007). Ljubljana: Ministry of Education and Sport. Tajfel, H. (1978). Introducing social psychology. London: Penguin Books.

Thomas, K. M., \& Chrobot-Mason, D. (2005). Group-level explanations of workplace discrimination. In R. L. Dipboye \& A. Colella (Eds.), Discrimination at work: The psychological and organisational bases (pp. 63-88). London: LEA.

Turnšek, N., \& Batistič-Zorec, M. (2009). Early childhood education and care in Europe: Tackling social and cultural inequality: Slovenia. Brussels: EACEA. Retrieved July 32013 from http://eacea. ec.europa.eu/about/eurydice/documents/o98_en_v2.pdf

Turnšek, N., \& Pekkarinen, A. (2009). Democratisation of early childhood education in the attitudes of Slovene and Finnish teachers. European Early Childhood Education Research Journal, 17(1), 23-42. Ule, M. (2004). Socialna psihologija [Social psychology]. Ljubljana: Faculty of Social Sciences. 
Van Dijk, T. A. (2005). Elite discourse and institutional racism. Retrieved July 32013 from http:// www.discourses.org/UnpublishedArticles/Elite\%2odiscourse\%2oand\%2oinstitutional\%2oracism. html

\section{Biographical note}

NADA TURNŠEK is an assistant professor of sociology of education at the Faculty of Education of the University of Ljubljana. She is lecturing Social Studies at the Undergraduate Early Childhood Education Study Program as well as subjects such as Democratization of preschool education, Comparative studies of education and Non-discriminatory practice at the Postgraduate study-level. Her main research work concentrates on exploring the teachers' subjective theories and their professional development, on comparative/culture studies of early childhood and educational values, as well as on exploring and promoting diversity and equality in pre-school settings. 


\section{Appendix:}

1. The security guard of the restaurant-bar 'Four Roses' is told to prevent Roma people from entering the premises. The owner argues that during the last few months there have been numerous thefts in the restaurant, and that he wants his clients to feel safe. (Roma/restaurant)

2. A preschool centre is attended by a girl who is often absent because she suffers from asthma. The teacher claims that her pedagogical work is affected due to the girl's frequent absences and late arrivals in the morning. Therefore, the principal proposes to the parents that they take the girl out of the preschool and find more appropriate day care. In response to the parents' complaint, the principal explains that their preschool centre has an internal policy according to which children who do not attend the preschool at least three times a week do not need day care. (Asthma)

3. Mr Favili teaches geography in a Catholic boys' boarding school. He has never spoken about his private life, but one day at the school's annual Christmas party he presents his male partner to his colleagues and the principal. During the Christmas holidays, he is given notice with an explanation that his lifestyle is not in line with the schools' ethical values and he is therefore no longer suitable as a teacher. (Gay)

4. A preschool centre has a problem because it cannot enrol all of the children who need day care. Therefore, the committee at the centre decides that enrolment priority will be given to children whose parents are employed, because they need day care the most, and to children whose permanent residence is in the area of the preschool centre. (Enrolment criteria)

5. In the process of selecting candidates for the Early Childhood Education course at the Faculty of Education, the candidates' musical abilities are tested. A candidate who did not demonstrate any musical ear was rejected. (Musical ear)

6. Due to downsizing the number of units in a preschool centre, the principal is forced to dismiss staff. Among the first on the list who will lose their jobs are single women under 30 years of age. The principal explains to the collective that young and single people have more opportunities to find a new job. (Age/ marital status) 
7. A political party decided to offer 50\% of the leading functions to women. The "affected" men complain because they think they are as capable of performing the leading functions as women. (Women/quota)

8. A well-known Slovenian company wishes to help young people of Roma origin in their entrance to the labour market, so the management agrees to establish a temporary quota of four jobs for apprentices of Roma origin. Frank, a young boy of Slovenian origin, applies for an apprenticeship in the company. In reply, he receives a letter saying: "Unfortunately, we cannot offer you an apprenticeship due to giving priority to candidates of Roma origin in accordance with our new programme. We will keep your application in our register for any potential future needs. We wish you every success." (Roma/employment) 